\title{
WATER RESOURCES OF BRITAIN
}

\begin{abstract}
A BROADSHEET, "Policy for Water" (No. 418 ; January 27, 1958), issued by Political and Economic Planning, attempts to give the background to the problem of water resources and supply by sketching the history and development of the water industry and other organizations concerned with the exploitation, disposal and conservation of water. Current economic and technical problems of supply and demand and pricing are then reviewed, including the need for more information, and the Broadsheet next discusses the two main administrative problems : first, the urgent need for a comprehens. ive rationalization of local water undertakings; and secondly, the need for greater co-ordination in all matters concerning water supply, fisheries, drainage, etc.

Pending the publication of the reports of the sub. committees appointed by the Central Advisory Water Committee, Political and Economic Planning concludes provisionally that the water resources of Britain are likely to be adequate to meet foreseeable demands,
\end{abstract}

but that much new capital must be expended if water is always to be available in adequate quantity or appropriate quality wherever it is needed. The Broadsheet points out that while water of high quality is essential for drinking purposes, low-grade water will often serve industrial needs, and it is desirable that increasing attention should be given to this aspect and that we should not continue to draw on our relatively searce resources of pure water for purposes for which water of inferior quality would do equally well.

There are far too many authorities. A radical rationalization of the water-supply industries is long overdue and is essential for substantial progress, although the basic technical economic problems of water supply can only be served if adequate capital is provided. Procedures laid down in the current Water Acts are long and intricate, and further measures may be required to overcome the natural unwillingness of many authorities to acquiesce in their own extinction within a reasonable time.

\section{DIATOMS FROM EQUATORIAL INDIAN OCEAN CORES}

$\mathrm{T}$ HE appearance of the ninth volume of the reports of the Swedish Deep-Sea Expedition 1947-1948* completes Dr. R. W. Kolbe's trilogy on the diatoms from the equatorial zones of the most traversed oceans. The material here reported consisted of twenty-three cores selected from those obtained from the Indian ocean by M/S Albatross under the leadership of Prof. Hans Pettersson.

The cores were taken with a Kullenberg sampler and some of them from a depth exceeding $5,000 \mathrm{~m}$. were more than $11 \mathrm{~m}$. in length. As the complete examination of so large a mass of material would be impracticable, three samples were usually taken from each, namely, one from the deepest layer, one from the uppermost layer, and one midway between. The cores chosen for this study had been shown by preliminary survey to contain diatoms, and after submitting the material to the usual acid-cleaning technique it was mounted for microscopical examination.

The cores selected were obtained from seven geographical regions: (1) Java, (2) East Indian Ocean, (3) Ceylon, (4) Maldives, (5) West Indian Ocean, (6) Seychelles, (7) African coast.

In this way samples were examined from inshore positions $(68 \mathrm{~m}$. depth) to positions of great oceanic depth of more than $5,000 \mathrm{~m}$.

By his use of the term 'diatom assemblage' Kolbe has rendered a great service in stressing the relation, or lack of it, between the silica unicells of the sediments and the diatom flora living in the column of water immediately above them. This abyssal assemblage differs from the planktonic and benthonic populations from which it is derived not only in a reduced number of species, but by their differing numerical frequencies. This assemblage is therefore not a natural facies of living organisms but belongs to a thanatocœnosis.

* Göteborgs Kungl. Vetenskaps- och Vitterhets-Samhalle. Reports of the Swedish Deep-Sea Expedition 1947-1948. Vol. 9: Sediment Cores from the Indian Ocean. No. 1: Diatoms from Equatorial Indian Ocean. By R. W. Kolbe. Pp. $50+4$ plates.
Elanders Boktryckeri Aktiebolag, 1957.) $15 \mathrm{Sw} . \mathrm{kr}$.
Further, the physico-chemical selection which is brought to bear upon dead and dying diatoms during their slow journey through great oceanic depths to the sea floor is largely responsible for the marked uniformity observed in the diatoms over wide regions of the ocean floor. Dr. Kolbe's researches have also led him to observe a marked similarity between the diatom assemblages of the Atlantic ${ }^{1}$, Pacific $^{2}$ and Indian oceans, and that the most frequent species are not confined to any one area, and that they differ only by their relative frequencies in the different areas. For example, Coscinodiscus nodulifer, Ethmodiscus (fragments) and Nitzschia marina are the commonest and most frequent species in all three equatorial oceans. Five others, Hemidiscus cuneiformis, Thalassionema sp., Coscinodiscus excentricus, Coscinodiscus lineatus and Coscinodiscus africanus, are common to the sediments of the three areas, but differ in their relative frequencies in the different oceans. These eight species constitute what Kolbe describes as the dominant abyssal assemblage.

One of the most interesting problems in diatom occurrence in oceanic cores is that concerning Ethmodiscus rex (Wall.) Hendey. This diatom, the largest known, lives or has lived in the three equatorial oceans and enormous deposits of it have been recorded from various parts. It is one of the most common diatoms in the equatorial sediments of the three oceans. For example, an area of oceanic ooze some three thousand miles long by twenty wide, consisting almost entirely of Ethmodiscus, has been reported between Guam and Luzon. Kolbe also has found evidence of considerable deposits of this species in the Indian and Atlantic Oceans-yet records of living specimens in the plankton have been rare.

Kolbe seeks to explain the discrepancy between the scarcity of Ethmodiscus rex in the plankton and its abundance and frequency in oceanic sediments, by combining three possible hypotheses: (1) dysphotic habit, explaining the rarity of the species in plankton 
samples taken by usual techniques (Karsten's hypothesis) ; (2) periodicity of short duration of mass reproduction (Hendey's hypothesis) ; (3) resistance to corrosion (Kolbe's hypothesis). Kolbe is of the opinion that the great accumulation of Ethmodiscus fragments in certain limited areas of the sea floor may be explained by the complicated relations between currents, sea-floor topography, size and form of sediment particles, all of which might result in a constant deposition of particles of certain properties in certain circumscribed areas.

Thus Ethmodiscus fragments within a certain size range might be constantly deposited at a given place, and so form Ethmodiscus beds, while other particles less dependent on slow currents might be distributed in a very different way.

Those who have tried to understand something of the relation between oceanic deposits, and the distribution of the living plankton populations that contribute to their formation, will find Dr. Kolbe's stressing of the differences between thanatocœnesis and biocœenesis of the greatest interest.

It seems that these differences must be influenced by the following factors (among others) :

(1) Chemical erosion, as stressed here by Dr. Kolbe.

(2) Rate of fall. Here the wide range in sinking rate of fragments derived from the one species Ethmodiscus rex, determined experimentally by Dr. Kullenberg, seems especially significant.

(3) Speed and direction of sub-surface currents. Recent physical observations, albeit in a very different part of the world, show that their speed may be much greater than Dr. Kolbe felt entitled to assume (cf. ref. 3).

(4) Extreme periodicity in local swarming of certain species of plankton diatoms, as postulated by Hendey ${ }^{4}$. Probably most plankton workers of long experience can recall odd instances supporting this view, but not, unfortunately, with regard to Ethmodiscus itself. The relative lack of samples from its apparent habitat is probably quite sufficient to account for this.

These four factors are very well presented in Dr. Kolbe's paper, but it is felt that yet another may be important :

(5) What might be termed the biological part in the breakdown and decay of plankton diatom frustules. The ingestion of frustules or fragments by mesoplankton animals may be repeated several times before they reach bottom, with the further probability of considerable bacterial action both before and after ingestion (cf. ref. 5). This may well be of great importance in determining which members of the biocœnosis remain recognizable in the thanatocœnosis.

One minor correction to Dr. Kolbe's paper is necessary. The record of dense swarms of Ethmodiscus in the Bay of Bengal does not occur in Collingwood's paper of 1868, in Transactions of the Royal Microscopical Society, the reference quoted, but in the discussion following the reading of the paper (Quart. J. Micr. Sci., 115; 1868), as Hendey has explained. The paper has now become a rarity, and some of the surviving separates do not include the discussion. The actual observations concerning Ethmodiscus in the Bay of Bengal seem to have been made by Dr. Wallich in 1851 and 1857.

The number of benthonic diatoms (112 taxa) observed in the material was 56 per cent of the total and was far greater than in the sediments of the Atlantic and Pacific Oceans. This is accounted for by the number of cores taken close to land. The high number of benthonic forms taken from the vicinity of the Seychelles archipelago, however, presents several interesting problems, as the cores were taken at great depth and far from the African mainland. It is suggested that their presence indicates that the whole district may have formerly belonged to a shallow sea and that its floor might have sunk to its present considerable depth at a not very remote period. The benthonic diatoms are, with very few exceptions, provided from thirteen of the twentythree cores examined. The cores from the Ceylon, Maldives, and East Indies areas provided but six species. The paucity of Triceratium species, particularly those belonging to the T. favus group, and of Mastogloia and Amphora in the Java cores is surprising, as these genera are well represented in the area. The occurrence of species of Stictodiscus, usually considered to be extinct, at widely separated areas is significant. Mann ${ }^{6}$ showed in his work on the diatoms of the Philippine Islands that the genus is well represented there and it may be that isolated pockets of these species have persisted since the Tertiary. Those in the African cores were found at depths varying from $4 \mathrm{~cm}$. to $10 \mathrm{~m}$.

Dr. Kolbe is to be congratulated upon completing this very considerable task without yielding to the temptation of making a host of new species out of the wide range of variants that the abyssal assemblage offered.

N. INGRAM HENDEY

${ }^{1}$ Kolbe, R. W., Rep. Swed. Deep-Sea Exped., 7, 149-184 (1955).

${ }^{2}$ Kolbe, R. W., Rep. Swed. Deep-Sea Exped., 6, 1-49 (1954).

${ }^{3}$ Swallow, J. C., and Worthington, L. V., Nature, 179, 1183 (1957).

"Hendey, N. Ingram, in Wiseman and Hendey, "Deep Sea Research", $1,47-49$ (1953).

s Hart, T. J., Discovery Reports, 8, 11, 186 (1934) ; 21, 327 (1942).

- Mann, A., U.S. National Museum Bull. 100, 6, 1 (1925).

\title{
SOLAR ACTIVITY AND RADIO COMMUNICATION
}

\author{
By R. NAISMITH \\ Radio Research Station (Department of Scientific and Industrial Research), Slough
}

GEVERAL years ago the period 1957-58 was $S$ selected as the International Geophysical Year in the expectation that it would coincide with a period of high solar activity. This long-term prediction has proved quite successful, since it is actually coinciding with the highest period of solar activity which has occurred within the past two hundred years. The success of this long-term prediction, however, must be considered in relation to a com. paratively large number of failures which make anyone who is aware of the difficulties involved reluctant to make long-period predictions until more is known of the causes of the variations.

There are, however, particular parts of the sunspot cycle which can be more accurately predicted than others for intermediate periods up to twelve months. 